\title{
TENSÃO ENTRE RACIONALIDADES: ESTUDO DE CASO DA ASSOCIAÇÃO DE CATADORES DE MATERIAIS RECICLÁVEIS DE LAVRAS (ACAMAR) ${ }^{1}$
}

\author{
Camila Pereira de Souza \\ Valderí de Castro Alcântara ${ }^{2}$ \\ Alyce Cardoso Campos \\ Ananda Silveira Bacelar \\ Érica Aline Ferreira Silva Yamamoto
}

\begin{abstract}
RESUMO
O presente trabalho trata de uma pesquisa social qualitativa, realizada em um empreendimento econômico solidário de catadores de materiais recicláveis, na cidade de Lavras, Minas Gerais. O objetivo do estudo consiste em compreender os efeitos das tensões entre as racionalidades substantiva e instrumental na gestão da ACAMAR (Associação de Catadores de Materiais Recicláveis de Lavras). Para a coleta de dados foram utilizadas técnicas de pesquisa documental, observação participante e entrevista semiestruturada. As análises ocorreram em quatro momentos: investigação de cada elemento constitutivo de ação substantiva e instrumental; mapeamento dos indicadores predominantes; identificação das tensões existentes; e compreensão dos efeitos das tensões no cotidiano organizacional e na gestão. Os resultados alcançados mostraram que a maioria das ações administrativas da ACAMAR são subsidiadas tanto pela lógica substantiva quanto pela lógica instrumental e, por conseguinte, as tensões entre elas são frequentes no cotidiano do empreendimento e nos processos de gestão. Mostrou-se também que os catadores lidam com a tensão na ACAMAR de duas formas: nada fazem a respeito, na medida em que não reconhecem sua existência; ou, ao reconhecerem sua existência tentam eliminá-la, porque a consideram indesejável. Portanto, em razão dessa forma na qual as tensões são encaradas pelos associados, o ambiente interno da Associação é marcado, mesmo com traços de substantividade por atritos, apatia, insatisfação, sentimento de não realização humana e não melhoria do êxito produtivo.
\end{abstract}

Palavras-chave: Racionalidade Substantiva. Racionalidade Instrumental. Tensões.

\section{TENSION BETWEEN RATIONALITIES: CASE STUDY OF THE ASSOCIATION OF COLLECTORS OF RECYCLABLE MATERIALS OF LAVRAS (ACAMAR)}

\begin{abstract}
The present work dealswith a qualitative social research, carried out in a solidary economic enterprise of recyclable material collectors, in the city of Lavras, Minas Gerais. The aim of the study is to understand the effects of tensionsbetween substantive and instrumental rationalities in the management of ACAMAR (Associação de Catadores de Materiais

${ }^{1}$ Como citar este artigo:

SOUZA, C. P. de et al. Tensão entre racionalidades: estudo de caso da associação de catadores de materiais recicláveis de Lavras (ACAMAR). ForScience, Formiga, v. 8, n. 2, e00788, jul./dez. 2020. DOI: 10.29069/forscience.2020v8n2.e788.

${ }^{2}$ Autor para correspondência: Valderí de Castro Alcântara: valderidecastroalcantara@ gmail.com
\end{abstract}


Recicláveis de Lavras). For data collection, documentary research techniques, participant observation and semi-structured interviews were used. The analyzes took place in four moments: analysis of each constitutive element of substantive and instrumental action; mapping of the predominant indicators; identification of existing tensions; and understanding the effects of tensions on organizational and management daily life. The results achieved showed that most of ACAMAR's administrative actions are subsidized by both substantive and instrumental logic and, therefore, tensions between them are frequent in the daily life of the enterprise and in the management processes. It was also shown that waste pickers deal with the tension at ACAMAR in two ways: they do nothing about it, insofar as they do not recognize its existence, or when they recognize its existence, they try to eliminate it, because they consider it undesirable. Therefore, due to the way in which tensions are faced by members, the internal environment of the Association is marked despite the traces of substantivity by friction, apathy, dissatisfaction, a feeling of human lack of fulfillment and an improvement in productive success.

Keywords: Substantive rationality. Instrumental rationality. Tensions.

\section{INTRODUÇÃO}

No atual cenário do Brasil, a crise do mercado formal de trabalho tem integrado a pauta de diversos debates. O problema do trabalho precarizado, do desemprego e da exclusão socioeconômica é realidade principalmente das classes baixas na estratificação social. Nesse sentido, ações alternativas geradoras de emprego, distribuição de renda e desenvolvimento local sustentável, fazem-se necessárias para a superação dessa condição de vulnerabilidade.

A Economia Solidária emergiu como um novo modelo de relações sociais de produção, comercialização e consumo de bens e serviços, centrada na valorização do ser humano e não do capital. Segundo Porto e Opuszka (2015) ela está alicerçada em quatro princípios básicos, são eles: autogestão, cooperação, solidariedade e democracia. Singer (2000) afirma que a Economia Solidária atua com o propósito de criar possibilidades reais de inclusão social por meio dos empreendimentos solidários, como cooperativas populares e associações.

Em apoio aos Empreendimentos Econômicos Solidários (EES) surgiram as Incubadoras Tecnológicas de Cooperativas Populares (ITCPs). A ITCPs são projetos, programas ou entidades vinculadas a instituições de ensino superior e que prestam apoio, capacitação e acompanhamento de grupos de trabalhadores, configurando-se como agentes de um processo educativo para a cooperação e a autogestão (GUERRA; PERREIRA, 2010). Essas ITCPs formam uma rede, a Rede Universitária de Incubadoras Tecnológicas de Cooperativas Populares, criada em 1999 com o objetivo principal de desenvolver e disseminar estudos sobre Economia Solidária, Associativismo, Cooperativismo Popular, Autogestão, 
dentre outros. Além disso, "ela surge para integrar de forma dinâmica as incubadoras e favorecer a transferência de tecnologias, metodologias e conhecimentos" (ITCP, 2018).

Nesse contexto, foi fundada, em 2005, a Incubadora Tecnológica de Cooperativas Populares da Universidade Federal de Lavras (INCUBACOOP/UFLA). A INCUBACOOP é um órgão integrante da Pró-reitora de Extensão e Cultura (PROEC) e da Rede Nacional de ITCPs, com função gerenciadora e executiva de projetos de incubação, pós-incubação de grupos de pessoas e empreendimentos econômicos solidários da microrregião de Lavras, sul de Minas Gerais. Atualmente a Incubadora trabalha com diversos empreendimentos solidários, dentre eles a Associação de Catadores de Materiais Recicláveis de Lavras (ACAMAR).

Uma associação de catadores de materiais recicláveis é constituída por trabalhadores de diferentes faixas etárias, que vivem em condições de vulnerabilidade socioeconômica e encontram na coleta seletiva uma fonte de renda (IPEA, 2013). A atividade realizada por estes trabalhadores "[...] consiste em catar, separar, transportar, acondicionar e, às vezes, beneficiar os resíduos sólidos com valor de mercado para reutilização ou reciclagem” (IPEA, 2013, p. 5). Portanto, proporcionam a transformação desses materiais em novos produtos e a reintrodução dos mesmos no ciclo produtivo gerando "benefícios positivos para a natureza e para a sociedade, já que promove a economia de recursos naturais e de espaços para o armazenamento dos resíduos" (MAGALHÃES, 2012, p. 14).

$\mathrm{Na}$ literatura sobre cooperativas e associações muito se discute sobre a racionalidade dessas organizações se diferenciar daquela das empresas (GUERRA; PEREIRA, 2010; MACHADO, 2017). De forma geral, é indicado que esses empreendimentos são geridos por meio de uma racionalidade substantiva e/ou comunicativa em detrimento de uma racionalidade instrumental. Contudo, os resultados de pesquisas acadêmicas (MACHADO, 2017; SILVA; SOUZA; ALCÂNTARA, 2018) e os resultados da aplicação do Diagnóstico Rápido Participativo Emancipador (DRPE), que consiste em uma das metodologias do processo de incubação utilizado pela INCUBACOOP, mostram que os associados da ACAMAR também apresentam uma racionalidade instrumental na gestão e organização de seu empreendimento. A partir de ampla literatura, Machado (2017) também mostra que nos estudos sobre cooperativas a racionalidade instrumental ainda é predominante.

O presente estudo segue a agenda de Machado (2017), a saber, "buscar desenvolver mais trabalhos que abordem a temática das racionalidades aplicadas às cooperativas" e associações (MACHADO, 2017, p. 129). E, também a chamada de Pereira e Cançado (2018) para desenvolver formas de gestão para estes tipos de organizações que não são pautadas na 
lógica mercantil. Considerando a relevância do estudo das tensões entre racionalidades nas organizações, o problema de pesquisa é: quais os efeitos da tensão entre a racionalidade substantiva e a instrumental na gestão da Associação de Catadores de Materiais Recicláveis de Lavras (ACAMAR)?

Portanto, esta pesquisa delimita algumas questões: a) a noção de tensão avança em uma perspectiva mais descritiva do que normativa dos empreendimentos; b) existe uma diversidade de racionalidades, tais como: substantiva, instrumental, comunicativa, ambiental etc., por isso foi realizada a delimitação; c) a escolha por tratar das racionalidades substantiva e instrumental foi teórica e metodológica - para esse debate existe a construção feita por Serva (1997a); d) entendemos que é possível analisar individualmente a existência e até a predominância de uma ou outra racionalidade, mas essa análise é incompleta; e) em decorrência disso, busca-se analisar as tensões e os efeitos delas para a gestão em empreendimento da economia solidária; e, f) a existência de "tensões" não é um pressuposto, mas, foi percebida nas atividades de extensão realizadas na ACAMAR.

A partir disso, o objetivo do presente estudo consiste em compreender os efeitos das tensões entre as racionalidades substantiva e instrumental, na gestão de um empreendimento econômico solidário de catadores de materiais recicláveis em Lavras, Minas Gerais.

Importante destacar que a partir da base conceitual dos trabalhos de Ramos (1981), Serva (1997b) desenvolveu-se um método capaz de demonstrar as racionalidades substantiva e instrumental nas ações administrativas de maneira empírica. Isto é, elaborou-se um quadro analítico que permite identificar qual das duas racionalidades predomina e como ela se concretiza nos processos de organizações produtivas reais. Diversas pesquisas aplicaram esse quadro de Serva (1997b) em variadas instituições brasileiras. Tais trabalhos foram classificados em: primeira geração do estudo teórico-empírico da racionalidade nas organizações; a segunda geração dos estudos, iniciada com a pesquisa de Silva (2009), além de codificar e sistematizar o aprendizado da primeira geração aprofundou a investigação da racionalidade ao ir além da identificação da predominância, ou seja, analisando as manifestações de tensões. É nessa geração de estudos que este trabalho se insere e dialogando com os textos de Serva (1997a; 1997b), Santos (2012), Santos e Serva (2013) e Siqueira (2017). 


\section{REFERENCIAL TEÓRICO}

Diversos cientistas sociais questionaram o conceito moderno de racionalidade, tais como Max Weber, Karl Mannheim, Max Horkheimer, Jürgen Habermas e Eric Voegelin (SIQUEIRA, 2017). Essa ideia de racionalidade, enquanto instrumento dirigido para a acumulação de bens e de riquezas ou de dominação econômica nas sociedades industriais ocidentais instigou Ramos (1981) a retomar o sentido clássico e rever o significado da racionalidade nas organizações. Assim, em sua obra "A nova ciência das organizações: uma reconceituação da riqueza das nações" faz a proposta de reformulação organizacional que resgata a racionalidade substantiva. Além disso, tinha o propósito de continuar sua pesquisa demonstrando tal racionalidade na prática administrativa (SIQUEIRA, 2017, p. 769).

Para Guerreiro Ramos (1983, p. 49) a ação administrativa, que consiste em um conjunto de atividades desenvolvidas no âmbito das organizações, "[...] é pautada entre a racionalidade funcional e a substantiva". Sendo a racionalidade funcional ou instrumental aquela que "[...] se revela como a capacidade de calcular probabilidades e desse modo coordenar os meios corretos com um fim determinado" (HORKHEIMER, 2002, p. 11). Assim, ela é uma "ação baseada no cálculo, orientada para o alcance de metas técnicas ou de finalidades ligadas a interesses econômicos ou de poder social, através da maximização dos recursos disponíveis" (SERVA, 1997a, p. 22). Por sua vez, a racionalidade substantiva é entendida "[...] como força cognitiva luminosa ativa na psique humana, dimensão de consciência crítica, capacidade de fazer julgamentos éticos e críticos de natureza pessoal, cuja ação é pautada pela intencionalidade" (SIQUEIRA, 2017, p. 769).

De acordo com Siqueira (2017), os estudos de Ramos e a emergência de empreendimentos sem finalidade lucrativa em todo o mundo impulsionaram avanços nas pesquisas sobre racionalidade nas organizações, entretanto, as análises se deram quase que exclusivamente na teoria e nas discussões epistemológicas: “[...] Foram incapazes de abordar a manifestação da racionalidade instrumental e da racionalidade substantiva na prática administrativa de maneira empírica, configurando-se assim um impasse no campo" (SIQUEIRA; SERVA, 2014, p. 2).

Tal impasse foi solucionado apenas por Serva (1996) que, a partir da base conceitual de Ramos, desenvolveu um quadro analítico que permite identificar qual racionalidade dentre a substantiva e a instrumental - predomina e como ela se concretiza nos processos administrativos em organizações produtivas reais (SIQUEIRA; SERVA, 2014, p. 2). 
Segundo Siqueira (2017), o predomínio da racionalidade substantiva em níveis elevados não exclui a existência da lógica racional instrumental em alguns processos administrativos ou vice-versa. Os estudos teórico-empíricos de Caitano (2010), Santos (2012) e Siqueira (2017) evidenciaram a coexistência dessas racionalidades na ação administrativa.

Para descrever a interação que estabelecem entre si, optou-se pelo termo "tensão", empregado com frequência por Ramos (SIQUEIRA, 2017, p. 770). Nesse contexto, tensão é entendida como uma área intermediária entre indivíduo e organização, razão substantiva e razão instrumental (RAMOS, 1981).

\begin{abstract}
A tensão é um símbolo linguístico empregado com frequência por Ramos (1981) para se referir à interação entre racionalidade instrumental e substantiva. Tensão, no contexto do presente trabalho, é entendida como em uma área intermediária da realidade onde a existência humana acontece, o in-between entre divino e humano, perfeição e imperfeição, razão e paixões inferiores, conhecimento e ignorância, imortalidade e mortalidade, pessoa humana e sociedade, indivíduo e organização, razão instrumental e razão substantiva (SIQUEIRA; SERVA, 2014, p. 2-3).
\end{abstract}

A partir de Ramos (1981) se observa um conflito crônico entre o sujeito e a organização, já que possuem "demandas concorrentes, nesse caso, os paradigmas da racionalidade instrumental e da racionalidade substantiva" (MUZZIO, 2014, p. 708). Por conseguinte, Ramos (1983) afirmou que uma ciência das relações humanas no trabalho não deve negar o conflito, uma vez que é impossível alcançar a homogeneidade das necessidades pessoais e organizacionais no cenário econômico, mas deve procurar estabelecer um acordo entre elas, mediante o equilíbrio das duas racionalidades.

É possível existir concordâncias, porém, como Almeida (2003) salientou, a tentativa de eliminar a tensão - principalmente por fatores ou forças externas - “[...] pode exacerbar os atritos e provocar tanto o não êxito produtivo quanto a apatia, a insatisfação e a não realização humana [...]" (SIQUEIRA, 2017, p. 770).

Finalmente, dos diferentes trabalhos para a análise das tensões, a melhor metodologia foi desenvolvida por Santos (2012). Na primeira coluna do quadro de análise de Santos (2012) apresentam-se os dois processos administrativos que orientaram a coleta de dados: o processo decisório e os valores e objetivos, com seus respectivos elementos constitutivos. Ademais, entre as duas colunas das racionalidades, há uma zona de tensão, na qual foram indicados seus elementos constitutivos. Assim, com base em tais elementos, também buscouse verificar a forma como se manifestam na prática administrativa desta associação de catadores de materiais recicláveis. 


\begin{tabular}{|c|c|c|c|}
\hline Processo & $\begin{array}{c}\text { Racionalidade } \\
\text { substantiva }\end{array}$ & Tensão & $\begin{array}{c}\text { Racionalidade } \\
\text { instrumental }\end{array}$ \\
\hline $\begin{array}{l}\text { Processo Decisório } \\
\text { Políticas e práticas de } \\
\text { gestão } \\
\text { Objetivos e metas } \\
\text { Efeitos } \\
\text { Pressões }\end{array}$ & $\begin{array}{l}\text { Autenticidade } \\
\text { Autonomia } \\
\text { Autorrealização } \\
\text { Entendimento } \\
\text { Julgamento ético } \\
\text { Satisfação Social }\end{array}$ & \multirow{2}{*}{$\begin{array}{l}\text { Características organizacionais } \\
\text { Ausência de consenso } \\
\text { Forças de pressão e influências } \\
\text { Inconformidade e convicções } \\
\text { Preferências pessoais e } \\
\text { organizacionais }\end{array}$} & $\begin{array}{l}\text { Cálculo } \\
\text { Êxito e resultados } \\
\text { Fins } \\
\text { Maximização de } \\
\text { recursos } \\
\text { Rentabilidade } \\
\text { Utilidade }\end{array}$ \\
\hline $\begin{array}{c}\text { Valores e objetivos } \\
\text { Identidade e padrões } \\
\text { Origem, difusão e } \\
\text { compartilhamento } \\
\text { Objetivos pessoais e } \\
\text { objetivos } \\
\text { organizacionais } \\
\text { Estímulo e realização }\end{array}$ & $\begin{array}{c}\text { Autenticidade } \\
\text { Autonomia } \\
\text { Autorrealização } \\
\text { Entendimento } \\
\text { Julgamento ético } \\
\text { Satisfação Social } \\
\text { Valores emancipatórios }\end{array}$ & & $\begin{array}{c}\text { Desempenho } \\
\text { Exxito e resultados } \\
\text { Fins } \\
\text { Rentabilidade }\end{array}$ \\
\hline
\end{tabular}

Quadro 1 - Análise da tensão entre racionalidades

Fonte: Santos (2012, p. 111).

Para a análise se utiliza dos elementos: "características organizacionais", "ausência de consenso", "forças de pressão e influências", "inconformidade e convicções", e, "preferências pessoais e organizacionais" (SANTOS, 2012). O Quadro 2 destaca o significado de cada um destes elementos das tensões.

\begin{tabular}{|c|c|c|}
\hline \multirow{5}{*}{ 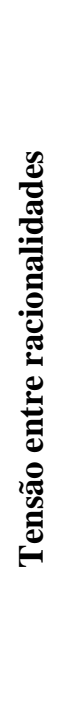 } & $\begin{array}{l}\text { Características } \\
\text { organizacionais }\end{array}$ & $\begin{array}{l}\text { Matta (1998) identificou que o tipo organizacional não necessariamente define } \\
\text { a sua racionalidade predominante. Assim, o grau de tensão na organização é } \\
\text { influenciado pelo seu contexto e estrutura (valores gerais; objetivos; meios, } \\
\text { normais ou táticas; participação; especificações de execução; perspectivas de } \\
\text { conhecimento dos fatos (RAMOS, 1983). }\end{array}$ \\
\hline & $\begin{array}{l}\text { Ausência de } \\
\text { Consenso }\end{array}$ & $\begin{array}{l}\text { O consenso parte da ideia de entendimento necessário para que as organizações } \\
\text { operem segundo suas expectativas de produtividade e eficácia e consigam uma } \\
\text { manutenção de padrões (RAMOS, 1983). }\end{array}$ \\
\hline & $\begin{array}{l}\text { Forças de pressão e } \\
\text { influências }\end{array}$ & $\begin{array}{l}\text { São fatores que exercem influência ou pressão na ação dos gestores; lealdade } \\
\text { organizacional (SIMON, 1970); cultura política (SHARKANSKY, 1974); } \\
\text { figuras de influência ou lideranças que proporcionam comportamentos passivos } \\
\text { (PINTO, 2001); força e compromisso do cargo/posição. }\end{array}$ \\
\hline & $\begin{array}{l}\text { Inconformidade e } \\
\text { convicções }\end{array}$ & $\begin{array}{l}\text { Elementos como sentimentos que podem causar falta de sentido ao trabalho } \\
\text { (CAITANO, 2010); consciência crítica; valores pessoais conflitantes com os } \\
\text { organizacionais. }\end{array}$ \\
\hline & $\begin{array}{l}\text { Preferências } \\
\text { pessoais e } \\
\text { organizacionais }\end{array}$ & $\begin{array}{l}\text { Divergência ou mistura de objetivos individuais e organizacionais; crenças } \\
\text { (SILVA, 2009); elementos que podem gerar facilidade ou dificuldade para } \\
\text { integração servidor-organização (ALMEIDA, 2002). }\end{array}$ \\
\hline
\end{tabular}

Finalmente, a partir de Santos e Serva (2013, p. 3), temos que as duas "racionalidades são vistas em um mesmo espaço e nas ações diárias de indivíduos" e que os indivíduos se encontram no meio das tensões em variados graus. A partir disso é possível analisar os efeitos das tensões. Portanto, não se trata apenas de identificar a tensão nos processos organizacionais, mas de verificar as consequências na gestão. 
Diversos estudos vêm sendo realizados sobre tensões entre racionalidades (Quadro 3). Estes foram trabalhos mapeados no Google Acadêmico, SciELO e SPELL.

\begin{tabular}{|c|c|c|c|}
\hline Título do trabalho & Autoria & Local & Ano \\
\hline $\begin{array}{l}\text { 1. Racionalidade nas organizações do terceiro setor: tensões e } \\
\text { implicações para a avaliação de programas sociais }\end{array}$ & Ramos & $\begin{array}{l}\text { Universidade de } \\
\text { Brasília } \\
\end{array}$ & 2006 \\
\hline $\begin{array}{l}\text { 2. Dificuldades entre racionalidade instrumental e } \\
\text { racionalidade substantiva na prática gestionária de profissionais } \\
\text { formados em curso de graduação em administração }\end{array}$ & Rodrigues & $\begin{array}{l}\text { Universidade Católica } \\
\text { de Goiás }\end{array}$ & 2006 \\
\hline $\begin{array}{l}\text { 3. Racionalidade administrativa e as pequenas empresas: } \\
\text { especificidades de gestão relacionadas à razão }\end{array}$ & Andrade & $\begin{array}{l}\text { Universidade de São } \\
\text { Paulo }\end{array}$ & 2010 \\
\hline $\begin{array}{l}\text { 4. Tensão entre as racionalidades substantiva e instrumental: } \\
\text { estudo de caso na ecovila Itapeba }\end{array}$ & Siqueira & $\begin{array}{l}\text { Universidade Federal } \\
\text { de Santa Catarina }\end{array}$ & 2012 \\
\hline $\begin{array}{l}\text { 5. A tensão entre a racionalidade substantiva e a racionalidade } \\
\text { instrumental na gestão pública: novos caminhos de um campo } \\
\text { de estudos }\end{array}$ & Santos & $\begin{array}{l}\text { Universidade Federal } \\
\text { de Santa Catarina }\end{array}$ & 2012 \\
\hline $\begin{array}{l}\text { 6. A tensão entre a racionalidade substantiva e a racionalidade } \\
\text { instrumental na gestão pública: novos caminhos de um campo } \\
\text { de estudo }\end{array}$ & $\begin{array}{l}\text { Santos; } \\
\text { Serva }\end{array}$ & EnANPAD & 2013 \\
\hline $\begin{array}{l}\text { 7. A condição paradoxal da administração de recursos } \\
\text { humanos: entre a racionalidade instrumental e a racionalidade } \\
\text { substantiva }\end{array}$ & Muzzio & Cadernos EBAPE.BR & 2014 \\
\hline $\begin{array}{l}\text { 8. Tensão entre racionalidades na abordagem substantiva das } \\
\text { organizações }\end{array}$ & $\begin{array}{l}\text { Siqueira; } \\
\text { Serva }\end{array}$ & $\begin{array}{c}\text { IV Colóquio } \\
\text { Internacional de } \\
\text { Epistemologia e } \\
\text { Sociologia da Ciência } \\
\text { da Administração } \\
\end{array}$ & 2014 \\
\hline $\begin{array}{l}\text { 9. Tensão entre racionalidades: estudo de caso na ecovila } \\
\text { Itapeba }\end{array}$ & $\begin{array}{l}\text { Siqueira; } \\
\text { Serva }\end{array}$ & $\begin{array}{c}\text { V Colóquio } \\
\text { Internacional de } \\
\text { Epistemologia e } \\
\text { Sociologia da Ciência } \\
\text { da Administração }\end{array}$ & 2015 \\
\hline $\begin{array}{l}\text { 10. Tensão entre racionalidades (instrumental e substantiva) em } \\
\text { paralelo a formas de cultura organizacional: um estudo de caso } \\
\text { em escola básica de tempo integral }\end{array}$ & Belluci & $\begin{array}{l}\text { Universidade Federal } \\
\text { de Santa Catarina }\end{array}$ & 2015 \\
\hline $\begin{array}{l}\text { 11. A tensão intrínseca à proteção e à manutenção do território } \\
\text { comunitário em formas não convencionais de organização: os } \\
\text { faxinais }\end{array}$ & $\begin{array}{l}\text { Silva; } \\
\text { Vizeu; } \\
\text { Seifert }\end{array}$ & $\begin{array}{l}\text { Revista científica } \\
\text { NORUS - Novos } \\
\text { Rumos Sociológicos }\end{array}$ & 2015 \\
\hline $\begin{array}{l}\text { 12. A análise da racionalidade nas organizações - um balanço } \\
\text { do desenvolvimento de um campo de estudos no Brasil }\end{array}$ & $\begin{array}{l}\text { Serva; } \\
\text { Caitano; } \\
\text { Santos; } \\
\text { Siqueira }\end{array}$ & Cadernos EBAPE.BR & 2015 \\
\hline $\begin{array}{l}\text { 13. Incubação de cooperativas populares: representações } \\
\text { sociais e tensões entre racionalidades }\end{array}$ & $\begin{array}{l}\text { Matarazzo; } \\
\text { Boeira }\end{array}$ & Cadernos EBAPE.BR & 2016 \\
\hline $\begin{array}{l}\text { 14. Análise das Incubadoras de Cooperativas Populares } \\
\text { (ITCPs) na perspectiva da razão substantiva e razão } \\
\text { instrumental }\end{array}$ & $\begin{array}{l}\text { Perret; } \\
\text { Miyahira; } \\
\text { Ometto }\end{array}$ & $\begin{array}{l}\text { XIX SEMEAD - } \\
\text { Seminários em } \\
\text { Administração }\end{array}$ & 2016 \\
\hline $\begin{array}{l}\text { 15. Tensão entre as racionalidades substantiva e instrumental: } \\
\text { estudo de caso em uma ecovila no sul da Bahia }\end{array}$ & Siqueira & Cadernos EBAPE.BR & 2017 \\
\hline $\begin{array}{l}\text { 16. Em busca da cooperação na gestão social: evidências de } \\
\text { uma categoria posta à coordenação de lógicas e espaços } \\
\text { híbridos do terceiro setor }\end{array}$ & $\begin{array}{l}\text { Alcântara; } \\
\text { Cabral; } \\
\text { Muzy; } \\
\text { Oliveira }\end{array}$ & $\begin{array}{l}\text { Revista de Gestão } \\
\text { Social e Ambiental - } \\
\text { RGSA }\end{array}$ & 2018 \\
\hline
\end{tabular}

Quadro 3 - Pesquisas sobre tensão entre racionalidades Fonte: Autores (2018). 
Isso mostra que diversos estudos vêm sendo realizados sobre as tensões, especialmente, na Universidade Federal de Santa Catarina. Sobre a questão temporal o Quadro 1 mostra que foi a partir de 2010 que houve um aumento no número de trabalhos com destaque para o ano de 2015. Nos últimos dois anos aparecem menos trabalhos sobre "tensões" isso pode ser em consequência das pesquisas sobre racionalidades estarem caminhando para a terceira geração interessada em temas como a pluralidade de regimes de ação a partir do referencial da Sociologia Pragmática Francesa.

\section{CAMINHOS METODOLÓGICOS}

\subsection{Natureza da pesquisa}

A presente pesquisa segue uma abordagem qualitativa que possibilita a leitura da realidade social e considera as subjetividades dos sujeito na pesquisa. Godoy (1995, p. 21) destaca que, na pesquisa qualitativa, é importante "obter informações por meio dos atores, um fenômeno que pode ser compreendido a partir da perspectiva das pessoas nele envolvidas, considerando todos os pontos de vista relevantes". O estudo é caracterizado como descritivo, uma vez que expõe com rigor o fenômeno da tensão entre as racionalidades na Associação de Catadores de Materiais Recicláveis de Lavras (ACAMAR), abrangendo detalhadamente os traços característicos desse empreendimento. Para Triviños (1987) a pesquisa descritiva busca descrever fatos e fenômenos de determinada realidade.

\subsection{Coleta de dados}

A pesquisa foi desenvolvida como um estudo de caso. No estudo de caso é possível analisar um fenômeno em seu contexto de forma ampla e utilizar de várias fontes de dados, bem como alcançar um conhecimento aprofundado (YIN, 2005). Os estudos de caso são importantes, principalmente, em pesquisas qualitativas: "o método de estudo de caso consiste na estratégia de pesquisa focada em casos individuais [que] oferece oportunidades de desenvolver conceitos e teorias [...]" (POTEETE; OSTROM; JANSSEN, 2011, p. 30). Conforme já exposto, o estudo de caso foi realizado com a ACAMAR.

A coleta dos dados foi realizada a partir da conjugação de três técnicas: (a) pesquisa documental, (b) observação participante e (c) entrevista semiestruturada, visto que os estudos de caso requerem a utilização de fontes múltiplas de evidências. Isso assegura o 
aprofundamento necessário ao estudo e a inclusão do caso em seu contexto, além de conferir maior fidedignidade aos resultados.

De acordo com Yin (2005), a existência de dados obtidos a partir de diferentes procedimentos possibilita a triangulação, isto é, confrontar as informações adquiridas por uma técnica com as outras, visando corroborar os resultados da pesquisa. Nesse sentido, para melhor entendimento do fenômeno da tensão entre as racionalidades substantiva e instrumental na ACAMAR, o processo de coleta de dados ocorreu da maneira ilustrada pela Figura 1.

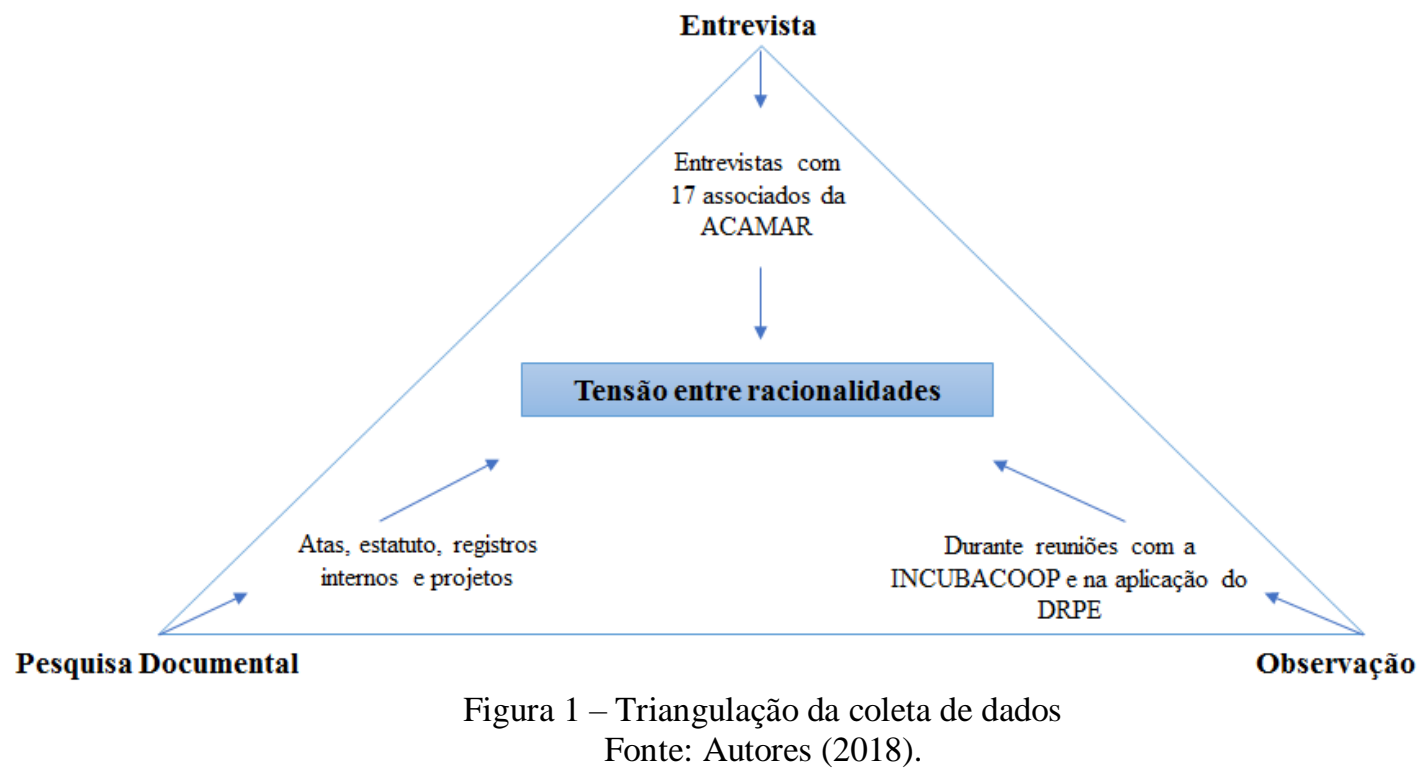

\section{(a) pesquisa documental}

Segundo Fonseca (1999, p. 32), a pesquisa documental utiliza fontes diversificadas e primárias, isto é, documentos escritos ou não, sem tratamento analítico, como: "tabelas estatísticas, jornais, revistas, relatórios, documentos oficiais, cartas, filmes, fotografias, pinturas, tapeçarias, relatórios de empresas, vídeos de programas de televisão, etc”. Além disso, os "documentos constituem uma fonte rica e estável de dados e subsistem ao longo do tempo" (DALBERIO; DALBERIO, 2009, p. 168). Assim sendo, este estudo levantou fotografias, cartilhas, atas de reunião, Estatuto e demais materiais da ACAMAR, bem como da INCUBACOOP relacionados à Associação indicados no Quadro 4. 


\begin{tabular}{|c|c|}
\hline Documento & Descrição \\
\hline Lista de Associados & $\begin{array}{l}\text { Planilha no Excel contendo o nome completo, CPF e RG de todos os } 37 \\
\text { (trinta e sete) associados. }\end{array}$ \\
\hline Cadastro de Associados & $\begin{array}{l}\text { Documentos que contêm informações básicas, socioeconômicas e de saúde } \\
\text { dos associados; bem como a declaração de livre associação de cada catador. }\end{array}$ \\
\hline Estatuto da ACAMAR & $\begin{array}{l}\text { Estatuto Social da ACAMAR aprovado em assembleia de fundação no dia } \\
01 \text { de março de } 2005 \text {. }\end{array}$ \\
\hline Regimento Interno & Regimento Interno aprovado no dia 18 de maio de 2009. \\
\hline $\begin{array}{l}\text { Ata da assembleia geral } \\
\text { extraordinária de eleição e } \\
\text { posse da diretoria e conselho } \\
\text { fiscal atual }\end{array}$ & $\begin{array}{l}\text { Ata da assembleia geral extraordinária de eleição e posse da diretoria e } \\
\text { conselho fiscal realizada no dia 06/12/2016, conforme edital de convocação } \\
\text { de } 28 / 11 / 2016 \text {. }\end{array}$ \\
\hline $\begin{array}{l}\text { Fotografias dos arquivos da } \\
\text { ACAMAR }\end{array}$ & Fotografias antigas da sede e dos associados da ACAMAR. \\
\hline Cartilha da ACAMAR. & $\begin{array}{l}\text { Cartilha que informa sobre a coleta seletiva, os materiais recolhidos pela } \\
\text { associação, bem como o dia e o período que o caminhão da ACAMAR } \\
\text { realiza a coleta nos bairros de Lavras. }\end{array}$ \\
\hline $\begin{array}{l}\text { Projeto CNPq de Estruturação } \\
\text { da INCUBACOOP/UFLA }\end{array}$ & $\begin{array}{l}\text { Projeto aprovado no CNPq (Ed 04/2008 - AT) com vigência de 01/08/2008 } \\
\text { a 31/07/2010. }\end{array}$ \\
\hline Projeto CNPq 2017-2018 & $\begin{array}{l}\text { Projeto aprovado no CNPq em } 2017 \text { (IEES 2017) "Incubação de } \\
\text { empreendimentos econômicos solidários de catadores Materiais } \\
\text { Recicláveis". Com vigência de } 24 / 11 / 2017 \text { a } 30 / 11 / 2018 \text {. O tempo foi } \\
\text { prorrogado por mais seis meses. }\end{array}$ \\
\hline Relatórios do DRPE & $\begin{array}{l}\text { Relatórios das aplicações das seis técnicas do DRPE na ACAMAR, } \\
\text { realizadas entre } 10 / 07 / 2017 \text { e 09/07/2018 }\end{array}$ \\
\hline $\begin{array}{l}\text { Relatório do evento em } \\
\text { homenagem à ACAMAR na } \\
\text { Câmara Municipal de Lavras }\end{array}$ & $\begin{array}{l}\text { Relatório do evento em homenagem à ACAMAR na Câmara Municipal de } \\
\text { Lavras, realizado no dia 25/06/2018, com a presença do presidente João } \\
\text { Paulo Felizardo, membros do gabinete de apoio, catadores da ACAMAR, } \\
\text { estudantes da escola Tiradentes, uma bolsista da INCUBACOOP e demais } \\
\text { convidados. }\end{array}$ \\
\hline Atas da INCUBACOOP & $\begin{array}{l}\text { Atas das reuniões gerais da equipe da Incubadora nas quais foram trados } \\
\text { assuntos sobre a ACAMAR, bem como atas das reuniões com dirigentes da } \\
\text { Associação, datadas de 23/01/2017 a 19/09/2018. }\end{array}$ \\
\hline $\begin{array}{l}\text { Fotografias dos arquivos da } \\
\text { INCUBACOOP }\end{array}$ & $\begin{array}{l}\text { Fotografias das aplicações das técnicas do DRPE; das tabelas, desenho e } \\
\text { diagrama construídos durante a realização dessas técnicas; das reuniões com } \\
\text { dirigentes da ACAMAR; do evento em homenagem à Associação na } \\
\text { Câmara Municipal de Lavras; e da sede do empreendimento. }\end{array}$ \\
\hline
\end{tabular}

Quadro 4 - Documentos analisados

Fonte: Autores (2018).

\section{(b) observação participante}

A observação participante, por sua vez, pode ser definida como "o processo no qual um investigador estabelece um relacionamento multilateral e de prazo relativamente longo com uma associação humana na sua situação natural com o propósito de desenvolver um entendimento científico daquele grupo" (MAY, 2001, p. 177). No presente trabalho a observação participante ocorreu durante as reuniões entre os membros da Incubadora e os associados do empreendimento, assim como na aplicação do Diagnóstico Rápido Participativo Emancipador (DRPE), uma das metodologias utilizadas pela INCUBACOOP no processo de incubação. Conforme Pereira (2017), o DRPE permite analisar a realidade, identificando os problemas, suas causas e possíveis soluções a partir da interação dialógica 
entre a equipe interdisciplinar responsável pela aplicação e o grupo social. Nesse sentido, consiste em um método de diagnóstico da realidade, de caráter essencialmente qualitativo, fundamentado na crítica coletiva e na mudança cultural. O Quadro 5 descreve as técnicas empregadas no DRPE.

\begin{tabular}{|c|c|}
\hline Técnica & Descrição \\
\hline Apresentação & $\begin{array}{l}\text { Identificação dos participantes do diagnóstico quanto a idade, estado civil, ocupação, } \\
\text { número de filhos e de dependentes. }\end{array}$ \\
\hline Mapeamento Histórico & $\begin{array}{l}\text { Desenho do mapa do local na percepção de seus moradores e descrição da situação } \\
\text { histórica das paisagens anteriores. }\end{array}$ \\
\hline Caminhada Transversal & $\begin{array}{l}\text { A equipe transdisciplinar caminha transversalmente o mapa desenhado pelo grupo } \\
\text { para constatar, in loco, a descrição feita por eles, fotografando e/ou filmando a } \\
\text { paisagem. }\end{array}$ \\
\hline Construção & $\begin{array}{l}\text { Consiste em promover a reflexão crítica de uma coletividade sobre as condições de } \\
\text { infraestrutura que possuem na atualidade e aquela que desejam construir no futuro } \\
\text { próximo. }\end{array}$ \\
\hline Calendário Sazonal & $\begin{array}{l}\text { Construção de um esquema gráfico onde as coordenadas } \mathrm{Y} \text { e } \mathrm{X} \text { representam, } \\
\text { respectivamente, a demanda relativa de força de trabalho, medida em dias de } \\
\text { trabalho, e as atividades ao longo dos meses de um ano. }\end{array}$ \\
\hline Rotina Diária & $\begin{array}{l}\text { Técnica complementar ao calendário sazonal que permite visualizar a distribuição do } \\
\text { trabalho ao longo do dia. }\end{array}$ \\
\hline Diagrama de Venn & $\begin{array}{l}\text { Representação gráfica, em forma de círculos, na interpretação dos participantes, da } \\
\text { importância e da atuação de organizações, entidades ou instituições que estão } \\
\text { presentes em suas vidas cotidianas, tendo como referência a própria organização. }\end{array}$ \\
\hline Entra e Sai & $\begin{array}{l}\text { Elaborada a partir de desenhos e representações gráficas, que permite aos } \\
\text { participantes uma melhor visualização dos seus gastos e receitas em cada atividade } \\
\text { produtiva ou de serviço desenvolvida. }\end{array}$ \\
\hline $\begin{array}{l}\text { Matriz Realidade e } \\
\text { Objetivo }\end{array}$ & $\begin{array}{l}\text { Elaboração de uma matriz onde são cruzadas as informações sobre os problemas, } \\
\text { suas causas e possíveis soluções apresentadas pelos participantes. }\end{array}$ \\
\hline Eleição de Prioridades & $\begin{array}{l}\text { Identificação das prioridades sociais, econômicas, políticas e técnico-produtivas do } \\
\text { grupo por meio da realização de uma eleição democrática. }\end{array}$ \\
\hline
\end{tabular}

(c) entrevista semiestruturada

As entrevistas foram agendadas com contatos prévios, por meio de ligações telefônicas, em dias e horários estabelecidos pelos profissionais. Assim, entre os dias 25 e 30 de julho de 2018 foram entrevistados 17 catadores de materiais recicláveis, sento 10 do sexo masculino e sete do sexo feminino. As entrevistas aconteceram na sede da Associação, durante o horário de expediente. A definição dos indivíduos a serem entrevistados, bem como a quantidade de entrevistas, se fundamentou no contrabalanço das seguintes considerações: o que se esperava dos entrevistados; a facilidade de acesso aos possíveis entrevistados, visto que alguns profissionais estavam desenvolvendo atividades fora da sede da ACAMAR; e a disponibilidade dos catadores que estavam na sede em participar. O Quadro 5 resume os processos de entrevista. 


\begin{tabular}{|c|c|c|c|}
\hline Data & Rótulo & Tempo & Perfil dos entrevistados \\
\hline $25-07-2018$ & Entrevistado 1 & $27 \mathrm{~min}$. & $\begin{array}{l}\text { Masculino, } 44 \text { anos, ensino fundamental incompleto, } 10 \text { anos } \\
\text { associado. }\end{array}$ \\
\hline $25-07-2018$ & Entrevistado 2 & $21 \mathrm{~min}$. & $\begin{array}{l}\text { Masculino, } 32 \text { anos, ensino fundamental completo, } 2 \text { anos e } 7 \\
\text { meses associado. }\end{array}$ \\
\hline $25-07-2018$ & Entrevistado 3 & $10 \mathrm{~min}$. & $\begin{array}{l}\text { Masculino, } 45 \text { anos, ensino fundamental incompleto, } 19 \text { anos } \\
\text { associado. }\end{array}$ \\
\hline $25-07-2018$ & Entrevistado 4 & $10 \mathrm{~min}$. & $\begin{array}{l}\text { Masculino, } 35 \text { anos, ensino fundamental incompleto, } 20 \text { anos } \\
\text { associado. }\end{array}$ \\
\hline $25-07-2018$ & Entrevistada 5 & 1h3min. & Feminino, 30 anos, ensino médio completo, 6 anos associada. \\
\hline $27-07-2018$ & Entrevistada 6 & $15 \mathrm{~min}$. & $\begin{array}{l}\text { Feminino, } 43 \text { anos, ensino fundamental incompleto, } 10 \text { anos } \\
\text { associada. }\end{array}$ \\
\hline $27-07-2018$ & Entrevistada 7 & $19 \mathrm{~min}$. & $\begin{array}{l}\text { Feminino, } 41 \text { anos, ensino fundamental incompleto, } \\
\text { aproximadamente } 7 \text { anos associada. }\end{array}$ \\
\hline 27-07-2018 & Entrevistado 8 & $15 \mathrm{~min}$. & $\begin{array}{l}\text { Masculino, } 26 \text { anos, ensino médio incompleto, } 4 \text { meses } \\
\text { associado. }\end{array}$ \\
\hline 27-07-2018 & Entrevistada 9 & $28 \mathrm{~min}$ & $\begin{array}{l}\text { Feminino, } 27 \text { anos, ensino médio incompleto, } 2 \text { anos e } 3 \text { meses } \\
\text { associada. }\end{array}$ \\
\hline 27-07-2018 & Entrevistado 10 & $19 \mathrm{~min}$. & $\begin{array}{l}\text { Masculino, } 42 \text { anos, ensino fundamental incompleto, } 9 \text { anos } \\
\text { associado. }\end{array}$ \\
\hline 27-07-2018 & Entrevistado 11 & $13 \mathrm{~min}$. & $\begin{array}{l}\text { Masculino, } 34 \text { anos, ensino fundamental incompleto, } 3 \text { meses } \\
\text { associado. }\end{array}$ \\
\hline $30-07-2018$ & Entrevistada 12 & $23 \mathrm{~min}$. & $\begin{array}{l}\text { Feminino, } 44 \text { anos, ensino fundamental incompleto, } 15 \text { anos } \\
\text { associada. }\end{array}$ \\
\hline $30-07-2018$ & Entrevistado 13 & $21 \mathrm{~min}$. & $\begin{array}{l}\text { Masculino, } 38 \text { anos, ensino fundamental completo, } 8 \text { dias } \\
\text { associado. }\end{array}$ \\
\hline $30-07-2018$ & Entrevistada 14 & $15 \mathrm{~min}$. & $\begin{array}{l}\text { Feminino, } 44 \text { anos, ensino fundamental incompleto, } 4 \text { anos } \\
\text { associada. }\end{array}$ \\
\hline $30-07-2018$ & Entrevistado 15 & $16 \mathrm{~min}$. & $\begin{array}{l}\text { Masculino, } 28 \text { anos, ensino fundamental incompleto, } 6 \text { anos } \\
\text { associado, } 16 \text { minutos e } 22 \text { segundos de entrevista }\end{array}$ \\
\hline $30-07-2018$ & Entrevistado 16 & $45 \mathrm{~min}$. & $\begin{array}{l}\text { Masculino, } 40 \text { anos, ensino fundamental incompleto, foi } \\
\text { associado de } 2007 \text { a } 2012 \text { e de } 2014 \text { até o momento, } 45 \text { minutos. }\end{array}$ \\
\hline $30-07-2018$ & Entrevistado 17 & $15 \mathrm{~min}$. & $\begin{array}{l}\text { Masculino, } 52 \text { anos, ensino fundamental incompleto, } 5 \text { anos } \\
\text { associado. }\end{array}$ \\
\hline
\end{tabular}

\subsection{Interpretação dos dados}

A interpretação dos dados foi realizada com base nos quadros de análise estruturados por Serva (1997a; 1997b), Santos (2012), Santos e Serva (2013) e Siqueira (2017). Dessa forma, foram realizadas quatro etapas. $\mathrm{Na}$ etapa 1 houve a análise de cada elemento constitutivo de ação substantiva e instrumental, isto é, identificou-se os indicadores presentes na ACAMAR. Na etapa 2, foi feito o mapeamento dos indicadores predominantes (SERVA, 1997b) para verificar qual racionalidade predomina e nesse processo construiu-se a escala do continuиm de intensidade de racionalidade substantiva e instrumental. Em um terceiro momento, finalmente, avançamos para a análise das tensões por meio do quadro de Santos (2012). A análise das tensões é realizada por meios dos seguintes elementos: Características organizacionais; Ausência de consenso; Forças de pressão e influências; Inconformidade e 
convicções e; Preferências pessoais e organizacionais. Com isso, na etapa 4 foram identificados os efeitos das tensões no cotidiano organizacional e na gestão da ACAMAR. Este artigo foca nesta última etapa da pesquisa.

\section{RESULTADOS E DISCUSSÃO}

\subsection{ACAMAR: uma breve história}

A ACAMAR foi a primeira associação de catadores de materiais recicláveis criada no município de Lavras/MG. Surgiu em 1998, a partir de trabalhos de educação ambiental desenvolvidos na cidade por estudantes da então Escola Superior de Agricultura de Lavras (ESAL), hoje UFLA, por meio da Fundação Pró Defesa Ambiental (FPDA).

Conforme os catadores relataram, inicialmente eram seis associados com uma renda líquida média mensal de aproximadamente $\mathrm{R} \$$ 50,00 (cinquenta reais). Para realizar as coletas dos materiais utilizavam uma carroça e uma mula cedidas pela Universidade Federal de Lavras. A Universidade também concedeu por 35 anos o uso do terreno no qual está localizada a sede da Associação. Ao longo dos anos seguintes conseguiram, por meio de projetos, mais equipamentos permanentes: caminhões, prensas, esteira, empilhadeira e fragmentadoras, utilizadas pelos catadores nas fases de triagem, compactação e armazenamento dos materiais.

A presença dos equipamentos é fundamental para os associados, pois agregam valor e eficiência aos processos. Eles auxiliam em processos que são pesados e que demandam muito esforço físico para serem executados. Além de obterem os equipamentos, os associados conseguiram, por meio de recursos externos, realizar melhorias nas instalações da sede da ACAMAR como, por exemplo, a construção da cozinha em 2005. Segundo os catadores, no ano de 2005, também elaboraram o Estatuto Social da Associação, embora a ACAMAR tenha sido criada na década de 1990. O Regimento Interno, por sua vez, foi elaborado quatro anos depois, em 2009.

Em abril de 2016, o então coordenador da ACAMAR e sua esposa foram demitidos. Nesse mesmo ano, houve renúncia do presidente da Associação. A atual Diretoria assumiu a frente do empreendimento com o desafio de tornar todas as questões internas transparentes, organizar a situação financeira da ACAMAR e tornar os catadores autogestionários, conforme é possível perceber nas falas dos entrevistados: 
A diretoria de agora é melhor, porque é tudo mais transparente (Entrevistada 6, feminino, 43 anos).

[...] quando assumi a ACAMAR eu pensei que seria um pouco mais fácil, porque quando tinha um coordenador as coisas eram meio que cobertas. Quando eu peguei e comecei ver mesmo [...] era cento e sessenta mil de dívida que a ACAMAR tinha dentro de Lavras. E assim, pensa bem... você pega um lugar que só tinha dívida, não tinha dinheiro. [...] Hoje em dia não, falta bem pouquinho graças à Deus para quitar essa dívida. Hoje eu acho que não está nem quarenta mil mais. Em dois anos [...]. Hoje em dia a ACAMAR só tem a conta de luz do mês exata. Não tem nenhuma conta de luz, nenhuma conta de água, nada atrasado. Nada dentro da ACAMAR hoje é atrasado como era quando assumi [...]. (Entrevistada 5, feminino, 30 anos).

Uma das ações da nova presidência da Associação foi procurar a INCUBACOOP em janeiro de 2017, após indicação da Incubadora de Empresas de Base Tecnológica (Inbatec/UFLA), para um possível auxílio no processo de mudança de gestão. O início da aplicação do DRPE se deu no dia 10 de julho de 2017 e a última técnica foi realizada dia 8 de julho de 2018.

Atualmente, a ACAMAR coleta cerca de 100 a 150 toneladas/mês de materiais recicláveis na cidade de Lavras. Atualmente, são ao todo 37 associados - 24 homens e 13 mulheres, com uma renda média mensal de aproximadamente R\$ 1.400,00 (mil e quatrocentos reais). Alguns deles trabalhavam antes em um aterro controlado - que na prática funcionava como um lixão - localizado às margens da BR-265, na comunidade do Itirapuã. Após a Prefeitura fechá-lo, os catadores foram encaminhados à associação:

Eu trabalhei lá no lixão [...] aí depois minha cunhada veio e depois da minha cunhada eu vim também. [...] lá era ruim de chuva. [...] eles fecharam o lixão e nós viemos pra cá (Entrevistada 7, feminino, 41 anos).

Quem entrou aqui primeiro foi meu pai e minha tia, porque foi na época que eles trabalharam no lixão [...] e a Prefeitura pôs eles aqui [...]. Meu primo também trabalhou no lixão, aí surgiu vaga e nós viemos. [...] lá eu trabalhei pouco tempo, acho que cinco meses só porque engravidei do meu menino, aí parei de ir. (Entrevistada 9, feminino, 27 anos).

Atualmente as principais demandas da ACAMAR, apontadas pelos associados são: a manutenção e conserto dos caminhões e prensas; e a aquisição de um outro espaço, capaz de comportar melhor o grande volume de resíduos. Algumas falas ilustram:

Aqui o espaço é pequeno para a gente trabalhar. Fica bem apertado, muito tumultuado (Entrevistada 6, feminino, 43 anos)

Pode melhorar, mas está bom por enquanto [...] tem um caminhão nosso que está estragado, arrumando ele poderia melhorar mais. Uma prensa ali está estragada, já podia melhorar mais (Entrevistado 8, masculino, 26 anos). 
Os problemas elencados pelos associados na aplicação do DRPE estavam relacionados à estrutura, à ausência de segurança e limpeza da associação, ao absenteísmo, à falta de manutenção de prensas e caminhões, bem como à carência de uniformes. Verificou-se que os associados desejam solucionar primeiramente a questão da falta de manutenção da prensa e do caminhão, devido à utilização constante desses recursos em prol do andamento da associação. Logo, seguiram com a questão da estrutura física, faltas dos associados, segurança, limpeza, relacionamento, e, por fim, uniformes. Sobre as demandas, eles afirmaram que diversas mudanças estruturais precisam ser realizadas, mas que não disponibilizam de recursos e que o ideal seria a construção de uma nova sede com espaço maior.

\subsection{Tensões entre racionalidades na ACAMAR e seus efeitos na gestão}

Os recentes trabalhos de Silva (2009), Caitano (2010), Serva et al. (2015) e Siqueira (2017), entre outros autores, apontaram o caráter restritivo da avaliação de predominância da racionalidade em organizações. Eles propuseram a análise da relação entre a lógica de ação substantiva e a lógica de ação instrumental no cotidiano das organizações. Dessa forma, para a investigação das tensões entre as racionalidades na ACAMAR, utilizou-se elementos constitutivos do quadro estruturado por Santos (2012) e Santos e Serva (2013).

Assim, com respeito às características organizacionais, verificou-se que os valores e objetivos presentes no contexto normativo do grupo e proferido pelos indivíduos são congruentes aos princípios do associativismo, do cooperativismo popular e da economia solidária - caracterizados por uma lógica de ação substantiva, conforme expresso na fala a seguir:

[...] aqui não tem patrão. Na empresa tem patrão e aqui não. Aqui nós somos dono (Entrevistado 4, masculino, 35 anos)

Não é um só que pode decidir as coisas. É reunião [...] e todos nós participamos (Entrevistado 8, masculino, 26 anos)

Se você trabalhou mais um pouco, você vai ganhar uma porcentagem maior. Você vai ganhar por aquilo que você trabalhou (Entrevistado 2, masculino, 32 anos).

Contudo, face às ações diárias dos catadores, notadamente pautadas na racionalidade instrumental, há uma contradição no cotidiano organizacional da ACAMAR:

Aqui, assim, todo mundo é dono. É um querendo mandar no outro (Entrevistada 9, feminino, 27 anos).

Às vezes minhas ideias e opiniões não são levadas em consideração. [...] deveriam me ouvir mais (Entrevistado 4, masculino, 35 anos). 
Muitos reclamam por causa de hora, uns reclamam que trabalham mais do que os outros [...], mas como é rotativo, cada semana um trabalha mais do que o outro, infelizmente. Aí sempre que a pessoa está no serviço que para mais tarde há reclamação (Entrevistado 15, masculino, 28 anos).

Percebe-se, na fala do entrevistado 15 que a tensão é negada (SIQUEIRA, 2017). A existência dessa contradição não é reconhecida pelos associados, inclusive pelos dirigentes, gerando, por conseguinte, apatia, insatisfação e não realização humana, observadas nas seguintes falas dos entrevistados:

Creio que alguns não estão satisfeitos [...] porque, assim, é a forma que o serviço hoje é feito (Entrevistado 15, masculino, 28 anos).

Pretendo ficar aqui no futuro só se não aparecer outra oportunidade melhor (Entrevistada 6, feminino, 43 anos).

Eu acho que na verdade não tem nem a competição. [...] a palavra certa seria [...] tranquilidade. Você vai ter aí um grupo que realmente tem um desejo muito grande de mudança, que tenta fazer as coisas caminharem [...] e o resto vai colocar a mochila nas costas e vai embora pra casa. (Entrevistado 16, masculino, 40 anos).

Sobre a negação das tensões, Siqueira (2017, p. 778) coloca que "a negação do conflito pode chegar a causar baixa produtividade e falta de competitividade da organização, que deixa de atender simultaneamente a expectativas utilitárias e substantivas".

No que se refere à ausência de consenso, foi observado que os catadores divergem quanto às normas e seu cumprimento, à execução das atividades e, principalmente, em relação às questões econômicas, conforme exposto:

Mudaria o horário para trabalhar. Sexta-feira para uma hora poderia parar mais tarde porque acumula muito o material. Para mim teria que trabalhar das sete até às cinco todo dia. Ia até duas, mas depois da discussão foi até três horas, três e meia (Entrevistado 17, masculino, 52 anos).

[...] Principalmente eu faria o Estatuto, as regras internas valerem com mais rigor. Porque às vezes abre a opção de facilitar para o associado, mas infelizmente mexer com o ser humano é difícil... Age na malandragem (Entrevistado 15, masculino, 28 anos).

Tudo que for relacionado a mexer no bolso... Pessoal fica bem agitado aí quando você tem que falar em dinheiro (Entrevistado 16, masculino, 40 anos).

O que chama a atenção é que, nesse aspecto, a tensão é gerada pelo fato de alguns catadores usufruírem das vantagens da forma de gestão de uma entidade associativa como, por exemplo, não ter chefe e poder determinar o próprio horário de trabalho para alcançarem seus objetivos individuais, em detrimento do restante do grupo. Nesse caso, seguindo as categorizações de Siqueira (2017), observa-se que a tensão é considerada indesejável. 
Os dirigentes por considerarem tais conflitos improdutivos tentam eliminá-los através de sanções ou mudanças nas regras, pressupondo a integração e a harmonia entre as demandas pessoais e organizacionais. Conforme Siqueira (2017), processos construídos dessa forma para eliminar a tensão podem se tornar danosos ao cotidiano organizacional. Entretanto, isso acaba provocando dentro da ACAMAR mais atrito e o não êxito produtivo.

Em relação às forças de pressão e influências, um dos dirigentes relatou, durante entrevista, que muitos associados exercem pressão na Diretoria a respeito do recebimento dos benefícios que a ACAMAR concede e que, em virtude dessa cobrança excessiva, já pensou em sair da Associação inúmeras vezes:

Essa cobrança do grupo em cima de mim, de ficar me cobrando muito: 'eu quero vale... a conta está bloqueada... eu quero a cesta'. Por causa dessa cobrança que foi vindo em cima de mim eu falei umas cinquenta vezes em sair da ACAMAR (Entrevistada 5, feminino, 30 anos).

Além disso, outro dirigente disse que há um grande conjunto de catadores que influencia negativamente aqueles indivíduos que acabaram de ingressar na ACAMAR:

O esforço a gente tem de poucos. Hoje a gente tem o [...], o [...], a [...], eu e uns novatos que chegaram, mas vai ficando e quando passa aí dois, três meses entra no clima dos outros. Então são sempre aqueles mesmos (Entrevistado 16, masculino, 40 anos).

No caso da fala do entrevistado 16, é demonstrado que a tensão existe, mas nada é feito para mudar a realidade. A partir dessas passagens, foi verificado que, embora os catadores tenham notado a presença de tensão nessas situações, não buscaram estabelecer um acordo entre os anseios da organização e as expectativas pessoais para atingir um equilíbrio entre as racionalidades substantiva e instrumental. Melhor dizendo, sequer assumiram verdadeiramente a existência da tensão, gerando consequentemente mais apatia, insatisfação e não realização humana.

O elemento inconformidade e convicções, que concerne à ausência de sentido do trabalho, à consciência crítica e aos valores particulares conflitantes com os do grupo (Santos, 2012), aparece em duas falas exemplares dos catadores:

[...] é cooperativismo, né? Aqui não tem (Entrevistada 6, feminino, 43 anos).

Não me imagino trabalhando aqui no futuro, porque [...] a visão do pessoal que tem aqui [...] é ainda muito pequena. Eles não abrem a mente para crescer. $\mathrm{O}$ que deixa a gente chateado é ver o potencial do empreendimento, ver as ferramentas que tem na mão, ver a possibilidade de crescer e não acatam as oportunidades que tem. As 
oportunidades vão passando, vão passando e a gente continua no mesmo lugar (Entrevistado 15, masculino, 28 anos).

Tais passagens remetem à constatação de que a maioria dos associados assumiu, em decorrência da gestão anterior, caracteristicamente centralizadora, um comportamento passivo e assentado na racionalidade instrumental. Esse comportamento tem se chocado com o envolvimento daqueles catadores que já incorporaram a administração participativa e, além disso, tem se contraposto aos valores e objetivos presentes no Estatuto e no Regimento Interno da ACAMAR. Isso pode ser comprovado na fala a seguir:

Ficamos mais de seis meses [...] só com o dinheiro da Associação mesmo, das cargas, reduzindo a renda dos catadores. Os catadores não entendiam muito. Tinha muito conflito porque, como as coisas ficavam meio escondidas, pra eles estava tudo certo. De repente você aparece com aquele tanto de conta, põe aquilo tudo na mesa. É desesperador para o grupo (Entrevistada 5, feminino, 30 anos).

Apesar da ambiguidade, a presença de tensão nessas situações também não é percebida pelos associados, acarretando insatisfação, não realização humana, atrito e o não êxito produtivo. Assim como Siqueira (2017, p. 781) que constatou a "tensão entre a ética pessoal e as exigências de sobrevivência econômica". Por fim, sobre as preferências pessoais e organizacionais ficou claro que são divergentes, uma vez que a maioria das ações e decisões dos catadores apresentam uma inclinação para a lógica instrumental, enquanto a ACAMAR, uma propensão à lógica de ação substantiva. Esse fato, além de gerar dificuldade para a integração indivíduo-organização, engendra uma contradição permanente no seio da Associação, verificada na fala de três entrevistados:

\footnotetext{
Eu acho que sim, que a ACAMAR é um empreendimento solidário (Entrevistada 6, feminino, 43 anos)

Não sei se a ACAMAR é um empreendimento solidário (Entrevistada 9, feminino, 27 anos)

Não considero a ACAMAR um empreendimento solidário (Entrevistada 12, feminino, 44 anos).
}

Apesar das contradições, a existência da tensão não é detidamente assumida ou sequer notada pelos catadores, propiciando apatia, insatisfação, não realização humana, atrito e o não êxito produtivo. A Figura 2 demonstra como os atores compreendem as tensões na Associação. 


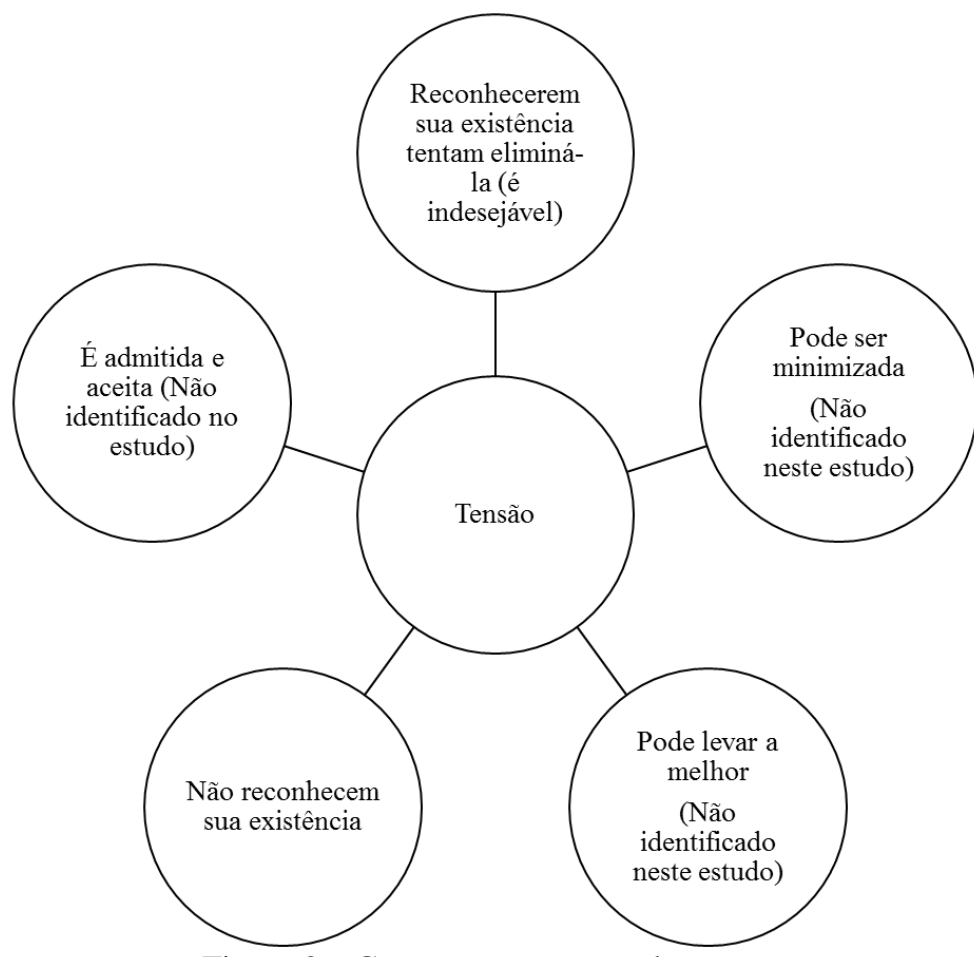

Figura 2 - Como os atores percebem as tensões

Fonte: Elaborado com base em Siqueira (2017).

Os resultados aqui encontrados podem ser comparados com os de Siqueira (2017) no contexto da sua pesquisa sobre ecovilas:

A criação de espaços para tomada de decisão e exercício da vida política que privilegiem a racionalidade substantiva não implica necessariamente redução dos espaços técnicos e burocráticos típicos da racionalidade instrumental. De fato, muitos dos conflitos e tensões experimentados pelos sujeitos nas ecovilas parecem ser atribuídos a uma gestão pouco eficiente e eficaz, do ponto de vista da racionalidade instrumental, e não à ausência de espaços substantivos institucionalizados. (SIQUEIRA, 2017, p. 778).

Finalmente, isso também abre possibilidade de refletir as cooperativas e associações dentro do paradigma paraeconômico de Ramos (1981).

Primeiro e acima de tudo, o padrão paraeconômico parte do pressuposto de que o mercado constitui um enclave dentro de uma realidade social multicêntrica, onde há descontinuidades de diversos tipos, múltiplos critérios substantivos de vida pessoal e uma variedade de padrões de relações interpessoais (RAMOS, 1981, p. 141).

Percebe-se que para os associados da ACAMAR o mercado é um enclave, mas não é o único - aliás, a relação desse enclave com outros mais substantivos gera as tensões. Além disso, na ACAMAR, os funcionários convivem com necessidades econômicas e outras individuais, éticas e de socialização. Finalmente, os associados não adotam completamente 
uma lógica de mercado: eles conseguem adotar também uma lógica social da gestão de cooperativas (PEREIRA; CANÇADO, 2018).

\section{CONSIDERAÇÕES FINAIS}

No campo da Gestão Social, as pesquisas sobre racionalidade que adotam a perspectiva das tensões são recentes. Dessa forma, trabalhos como este são importantes para dar continuidade e aprofundamento nessa nova vertente de análise do cotidiano organizacional, bem como para abordar sua manifestação na prática. Fica evidente a importância do estudo da razão que em um sentido mais substantivo é o "que habilita o indivíduo a distinguir entre o bem e o mal, entre o conhecimento falso e o verdadeiro e, assim, a ordenar sua vida pessoal e social” (RAMOS, 1981, p. 02-03).

Diante disso, os dados empregados neste estudo - coletados a partir da conjugação das técnicas pesquisa documental, observação participante e entrevista semiestruturada - foram analisados com base nos procedimentos de Serva (1997b) e Santos (2012), dentre outros. Dentre os 11 (onze) processos investigados, a maioria apresentou tanto elementos substantivos quanto instrumentais. No presente estudo constatou-se que as tensões são frequentes nas práticas administrativas da ACAMAR. Contudo, são percebidas pelos catadores apenas nas situações de ausência de consenso, bem como perante forças de pressão e influência. Os dirigentes, em ambos os contextos, não buscam minimizar a tensão, isto é, estabelecer um acordo para atingir o equilíbrio entre as racionalidades. A diretoria quando identifica conflitos tenta eliminá-los, por considerar a tensão indesejável.

Como consequência dessa forma na qual as tensões são encaradas pelos associados, o ambiente interno da ACAMAR é marcado por atritos, apatia, insatisfação, sentimento de não realização humana e não melhoria do êxito produtivo. Ademais, a existência de tensão entre as racionalidades substantiva e instrumental na ACAMAR corrobora o fato de que "a gestão do desenvolvimento social é um campo de conhecimento e espaço de práticas marcado pelo hibridismo e a contradição" e "o conflito de percepções e interesses está presente também em formas organizativas solidárias que, por sua vez, estão embebidas em contextos capitalistas ocidentais" (FISCHER, 2012, p. 117).

A INCUBACOOP poderá desenvolver, com base nos resultados produzidos por este estudo, tecnologias sociais de extensão que não extingam ou ignorem a tensão de forma tutorial, mas que fomentem os membros de empreendimentos econômicos solidários a conciliarem as suas expectativas pessoais com os anseios organizacionais. Esta pesquisa pode 
ser ainda fundamentação teórica e empírica para a INCUBACOOP passar a adotar na formação de estudantes, pesquisadores e instituições participantes por meio de assessoria e cursos, uma linha que exceda a avaliação de predominância da razão substantiva como ordenadora das organizações de cunho solidário.

As principais dificuldades foram especialmente no DRPE e atividades da INCUBACOOP, a saber: disponibilização de transporte para a equipe; quantidade restrita de pessoas para aplicar as técnicas; imprevistos nas atividades dos catadores; feriados e recessos acadêmicos que provocaram diversas vezes o adiamento das reuniões e aplicação das técnicas; apenas o presidente participou de todas as reuniões com a equipe da INCUBACOOP, propiciando a centralização das informações e uma visão unilateral da ACAMAR; quantidade de catadores que participaram da aplicação do DRPE foi relativamente baixa; catadores que se dispuseram a participar da aplicação do DRPE pressionavam a equipe da INCUBACOOP para terminar rapidamente as atividades; a maioria dos catadores que participaram da aplicação das técnicas do DRPE dialogava pouco com a equipe da INCUBACOOP; e, alguns associados questionaram quanto ao retorno, principalmente econômico, que teriam por estarem realizando o DRPE. Agora após a pesquisa, pode-se argumentar que isso se deve à presença das tensões entre as racionalidades instrumental e substantiva.

Sobre a forma jurídica um estudo a ser desenvolvido pode ficar na seguinte problemática: A ACAMAR é uma "associação", mas faz a distribuição pro-rata das operações (característica de uma cooperativa) e, alguns catadores possuem, em determinadas questões, concepções que se aplicam às empresas capitalistas: ela deve se legalizar como uma cooperativa ou a saída é ainda como uma empresa? A partir dos resultados encontrados na análise das racionalidades há possibilidades para ambas as formas.

Em estudos futuros é possível abordar as tensões entre racionalidades instrumental, comunicativa e substantiva. No entanto, no campo das racionalidades, muitos estudos já foram feitos a partir da racionalidade comunicativa de Habermas (2004), por isso, outro caminho pode se dar a partir do conceito de phronesis, sabedoria prática, que rompe com a dicotomia entre racionalidades e que leva também a uma ênfase nas práticas - abrindo espaço para contribuições via teóricos da prática. De forma geral, o desafio dos próximos trabalhos é estimular a construção de novas tecnologias sociais, cujos métodos ou instrumentos inovadores possam ser criados em conjunto pelos atores das comunidades, voltadas para o alcance da eficácia, da eficiência e dos valores éticos e emancipatórios em associações e cooperativas populares com natureza dual, decorrente da tensão entre as racionalidades. E, 
ainda, caminhando para a possibilidade de uma terceira geração de estudos sobre racionalidades e adentrar em temas como emoções e racionalidades e, ainda, a pluralidade dos regimes de ação em que diferentes elementos apareceram durante este trabalho.

\section{REFERÊNCIAS}

ALMEIDA, M. Empresas de economia de comunhão: possibilidade de valorização da racionalidade substantiva na organização econômica? Dissertação (Mestrado em Administração) - Pontifícia Universidade Católica. Rio de Janeiro, 2003.

CAITANO, D. A racionalidade substantiva na gestão organizacional: contribuição para consolidação de um campo de estudos. 2010. 184 f. Dissertação (Mestrado em Administração) - Universidade Federal de Santa Catarina, Florianópolis, 2010.

DALBERIO, O.; DALBERIO, M. C. B. Metodologia científica: desafios e caminhos. São Paulo: Paulus, 2009.

FISCHER, T. Gestão social do desenvolvimento de territórios. Revista Psicologia, Organizações e Trabalho. Florianópolis, v. 12, n. 1, p. 113-119, 2012.

FONSECA, J. J. S. Metodologia da pesquisa científica. Fortaleza: UEC, 2002.

GODOY, A. S. Pesquisa qualitativa: tipos fundamentais. Revista de Administração de Empresas, São Paulo, v. 35, n. 3, p. 20-29, 1995.

GUERRA, A. C.; PEREIRA, J. R. Incubadoras tecnológicas de cooperativas populares: possibilidades de gestão. Administração Pública e Gestão Social, Viçosa, v. 2, n. 1, p. 2144, 2010.

HABERMAS, J. Verdade e justificação: ensaios filosóficos. São Paulo: Loyola, 2004.

HORKHEIMER, M. Eclipse da razão. São Paulo: Centauro, 2002.

IPEA - INSTITUTO DE PESQUISA ECONÔMICA APLICADA. Situação social das catadoras e dos catadores de material reciclável e reutilizável. Brasília: Ipea, 2013. Disponível em:

http://www.ipea.gov.br/agencia/images/stories/PDFs/situacao social/131219 relatorio situac aosocial_mat_reciclavel_brasil.pdf. Acesso em: 30 mar. 2018.

ITCP - INCUBADORA TECNOLÓGICA DE COOPERATIVAS POPULARES. Programa de extensão universitária do Instituto Alberto Luiz Coimbra de Pós-graduação e Pesquisa de Engenharia (COPPE) da Universidade Federal do Rio de Janeiro (UFRJ). Rio de Janeiro: ITCP, 2018. Disponível em: http://www.itcp.coppe.ufrj.br/a_itcp_somos.php. Acesso em: 30 mar. 2018. 
MACHADO, J. C. Gestão de cooperativas: uma análise do tipo de racionalidade predominante. 2017. 144 f. Dissertação (Mestrado em Administração) - Universidade Federal de Lavras, Lavras, 2017.

MAGALHÃES, B. J. Liminaridade e exclusão: os catadores de materiais recicláveis e suas relações com a sociedade brasileira. 2012. 131 f. Dissertação (Mestrado em Antropoogia) Universidade Federal de Minas Gerais, Belo Horizonte, 2012.

MAY, T. Pesquisa social: questões, métodos e processos. Porto Alegre: Artmed, 2001.

MUZZIO, H. A condição paradoxal da administração de recurso humanos: entre a racionalidade instrumental e a racionalidade substantiva. Cadernos EBAPE.BR, Rio de Janeiro, v. 12, n. 3, jul./set. 2014.

PEREIRA, J. R. Diagnóstico Participativo: o método DRPE. Tubarão: Perito, 2017.

PEREIRA, J. R.; CANCADO, A. C. Gestão Social de Cooperativas. Curitiba: Appris, 2018.

PORTO, P. A. C.; OPUSZKA, P. R. Economia solidária, seus princípios e sua extensão como vetor para construção de um novo cidadão. Revista Jurídica, Curitiba, v. 1, n. 38, p. 422-441, 2015.

POTEETE, A. R.; OSTROM, E.; JANSSEN, M. A. Trabalho em parceria: ação coletiva, bens comuns e múltiplos métodos. São Paulo: Senac, 2011, 408 p.

RAMOS, A. G. A nova ciência das organizações: uma reconceituação da riqueza das nações. Rio de Janeiro: FGV, 1981.

RAMOS, A. G. Administração e contexto brasileiro: esboço de uma teoria geral da administração. Rio de Janeiro: FGV, 1983.

SANTOS, L. S. A Tensão entre a racionalidade substantiva e a racionalidade instrumental na gestão pública: novos caminhos de um campo de estudos. 2012. $262 \mathrm{f}$. Dissertação (Mestrado em Administração) - Universidade Federal de Santa Catarina, Florianópolis, 2012.

SANTOS, L.; SERVA, M. A Tensão entre a racionalidade substantiva e a racionalidade instrumental na gestão pública: novos caminhos de um campo de estudo. In: ENCONTRO DA ANPAD, 37., 2013, Rio de Janeiro. Anais [...]. Rio de Janeiro, 2013.

SERVA, M. Racionalidade e organizações: o fenômeno das organizações substantivas. 1996. 327 f. Tese (Doutorado em Administração) - Fundação Getúlio Vargas, São Paulo, 1996.

SERVA, M. A racionalidade substantiva demonstrada na prática administrativa. Revista de Administração de Empresas, São Paulo, v. 37, n. 2, p. 18-30, 1997a.

SERVA, M. Abordagem substantiva e ação comunicativa: uma complementaridade frutuosa para a teoria das organizações. Revista de Administração Pública, Rio de Janeiro, v. 31, n. 2, p. 108-134, 1997b. 
SIQUEIRA, G.; SERVA, M. Tensão entre racionalidades na abordagem substantiva das organizações. In: IV COLÓQUIO INTERNACIONAL DE EPISTEMOLOGIA E SOCIOLOGIA DA CIÊNCIA DA ADMINISTRAÇÃO, 2014, Florianópolis. Anais... Florianópolis, 2014.

SERVA, M. et al. A análise da racionalidade nas organizações - um balanço do desenvolvimento de um campo de estudos no Brasil. Cadernos EBAPE.BR, Rio de Janeiro, v. 13, n. 3, p. 414-437, 2015.

SILVA, M. Racionalidade substantiva no processo decisório: um estudo em instituições que lidam com o tratamento oncológico infanto-juvenil na cidade de Natal-RN. 2009. $107 \mathrm{f}$. Dissertação (Mestrado em Administração) - Universidade Federal do Rio Grande do Norte. Natal, 2009.

SINGER, P.; SOUZA, A. A economia solidária no Brasil: autogestão como resposta ao desemprego. São Paulo: Cortez, 2000. 360 p.

SIQUEIRA, G. M. V. Tensão entre as racionalidades substantiva e instrumental: estudo de caso em uma ecovila no sul da Bahia. Cadernos EBAPE.BR, Rio de Janeiro, v. 15, n. 4, p. 768-782, 2017.

TEIXEIRA, T. S. A construção dos sentidos e interesses no uso da água mineral pelas organizações da sociedade civil do município de Cambuquira-MG: um estudo à luz da gestão social. 2017. Trabalho de Conclusão de Curso (Graduação em Administração Pública) - Universidade Federal de Lavras, Lavras, 2017.

TRIVIÑOS, A. N. S. Introdução à pesquisa em ciências sociais: a pesquisa qualitativa em educação. São Paulo: Atlas, 1987.

YIN, R. K. Estudo de caso: planejamento e métodos. 3. ed. Porto Alegre: Bookman, 2005.

\section{DADOS DOS AUTORES}

Nome: Camila Pereira de Souza

E-mail: camilapsouza@admpublica.ufla.br

Curriculum Lattes: http://lattes.cnpq.br/1824420613040252

Graduação em Administração Pública pela Universidade Federal de Lavras.

Nome: Valderí de Castro Alcântara

E-mail: valderidecastroalcantara@gmail.com

Curriculum Lattes: http://lattes.cnpq.br/2870598651094370

Doutorado; mestrado em Administração pela Universidade Federal de Lavras; graduação em Administração pela Universidade Federal de Viçosa - Campus de Rio Paranaíba. Atualmente é professor e coordenador do curso de Administração da Universidade do Estado de Minas Gerais (UEMG) - Unidade Cláudio.

Nome: Alyce Cardoso Campos

E-mail: alycecardosoc@yahoo.com.br

Curriculum Lattes: http://lattes.cnpq.br/6701293188250747 
Doutoranda; mestrado em Administração na Universidade Federal de Lavras e graduação em Administração pela Universidade Federal de Juiz de Fora - Campus Governador Valadares onde foi fundadora e diretora de Marketing da Empresa Júnior TriVallis Consultoria (20142016). É membro do Grupo de Estudos em Marketing e Comportamento do Consumidor (GECOM) e do Grupo de Estudos em Redes, Estratégia e Inovação (GEREI) - UFLA.

Nome: Ananda Silveira Bacelar

E-mail: anandasbacelar@gmail.com

Curriculum Lattes: http://lattes.cnpq.br/1675961909144774

Graduação em Administração pela Universidade Estadual do Sudoeste da Bahia. Tem experiência na área de Administração. É membro do Núcleo de Estudos em Organizações, Gestão e Sociedade (NEORGS) - UFLA.

Nome: Érica Aline Ferreira Silva Yamamoto

E-mail: erica_alline@ hotmail.com

Curriculum Lattes: http://lattes.cnpq.br/7241580001284141

Doutoranda; mestrado e graduação em Administração pela Universidade Federal de Lavras. Atualmente é pesquisadora do Núcleo de Estudos em Administração Pública e Gestão Social (NEAPEGS). Professora do curso de Administração da Faculdade de Ciências Sociais Aplicadas do Sul de Minas. 